\title{
1 Techno-economic assessment of a Multi-effect Distillation plant installed for the production of irrigation water in Arica (Chile)
}

4 Palenzuela,.$^{(1)^{*}}$, Miralles-Cuevas, S. ${ }^{(2,3)}$, Cabrera-Reina, A. ${ }^{(2,3)}$, Cornejo-Ponce, L. ${ }^{(2,3)^{* *}}$

5 (1) CIEMAT-Plataforma Solar de Almería, Ctra. de Senés s/n, 04200 Tabernas, Almería, Spain

$6{ }^{(2)}$ Laboratorio de Investigaciones Medioambientales de Zonas Áridas (LIMZA), Universidad de 7 Tarapacá. Av. General Velásquez 1775, Arica, Chile

8 (3) Escuela Universitaria de Ingeniería Mecánica (EUDIM), Universidad de Tarapacá. Av. General 9 Velásquez 1775, Arica, Chile

11 Corresponding author 1: Ph.D. Patricia Palenzuela Ardila, (Plataforma Solar de Almería), 12 patricia.palenzuela@psa.es

13 Corresponding author 2: Ph.D. Lorena Cornejo Ponce (Universidad de Tarapacá), lorenacp@uta.cl

\section{Abstract}

16 In the context of a regional Chilean project (FIC Taltape project, BIP code 30158422-0), a

17 multi-effect distillation (MED) pilot plant has been built and installed in a small community

18 in the north of Chile (Taltape, Arica) in order to supply treated water for agricultural and

19 domestic purposes. The aim of this paper is to assess the techno-economic feasibility of this

20 system for supplying water with the required quality to the population. The characterization

21 of the feed water and the effluents from the MED pilot plant (distillate and brine), obtained

22 during five months of operation, has been firstly performed. Then, the prediction of the

23 operation of the water treatment system with solar energy has been carried out using a typical

24 meteorological year and the design of a static solar field that cover the thermal energy needs 25 of the water treatment plant.

27 The annual simulations of the MED pilot plant operating with solar energy showed that the 28 water needs can be mostly covered using a static solar thermal field with a total area of 
$29113.2 \mathrm{~m}^{2}$, which would generate roughly $46 \%$ of the total heat required by the water treatment

30 plant. The technical analysis has been completed with an exhaustive economic assessment.

31 The specific water costs have been determined for the MED pilot plant and the scale factor

32 when the productivity is increased up to $5,000 \mathrm{~m}^{3} /$ day has been evaluated. The cost of

33 distillated water produced by the MED plant varied from $15.0 \mathrm{USD} \$ / \mathrm{m}^{3}$ for the $10 \mathrm{~m}^{3} /$ day

34 production capacity to $1.25 \mathrm{USD} \$ / \mathrm{m}^{3}$ when this variable is increased to $5,000 \mathrm{~m}^{3} /$ day.

36 Keywords: Multi-effect distillation, brackish water treatment, arsenic and boron removal, modelling

37 and simulation, solar thermal water treatment

38

\section{Nomenclature}

$\begin{array}{cl}R & \text { Retention percentage (\%) } \\ C_{B F W} & \text { Concentration of the element in the brackish feed water }(\mathrm{mg} / \mathrm{L}) \\ C_{D} & \text { Concentration of the element in the distillate }(\mathrm{mg} / \mathrm{L}) \\ \Delta T_{e f f, i} & \text { Temperature difference between effects }\left({ }^{\circ} \mathrm{C}\right) \\ T_{v} & \text { Vapour temperature inside the effect }\left({ }^{\circ} \mathrm{C}\right) \\ N & \text { Number of effects } \\ Q_{s} & \text { Heat transfer rate provided to the first effect }(\mathrm{kW}) \\ T_{S} & \text { Temperature of the heating energy source supplied to the first effect } \\ M_{S} & \text { Steam mass flow rate supplied as the heating energy source to the first effect }(\mathrm{kg} / \mathrm{s}) \\ \lambda_{s} & \quad \text { Change in enthalpy related to the condensation of the steam supplied to the first } \\ & \text { effect }(\mathrm{kJ} / \mathrm{kg}) \\ U_{e} & \text { Overall heat transfer coefficient }\left(\mathrm{kW} / \mathrm{m}^{2} \cdot{ }^{\circ} \mathrm{C}\right) \\ M_{f} & \text { Feedwater mass flow rate }(\mathrm{kg} / \mathrm{s})\end{array}$




\begin{tabular}{|c|c|}
\hline$M_{g b}$ & Total vapour generated inside the effect $(\mathrm{kg} / \mathrm{s})$ \\
\hline$\lambda_{g b}$ & Latent heat of vaporization $(\mathrm{kJ} / \mathrm{kg})$ \\
\hline$C_{p}$ & Specific heat $\left(\mathrm{kJ} / \mathrm{kg} \cdot{ }^{\circ} \mathrm{C}\right)$ \\
\hline$T_{f}$ & Temperature of the feedwater that reaches the first effect $\left({ }^{\circ} \mathrm{C}\right)$ \\
\hline$M_{\text {prod }}$ & Total distillate obtained from the water treatment plant $(\mathrm{kg} / \mathrm{s})$ \\
\hline$R R$ & Recovery Ratio \\
\hline$S A$ & Specific area $\left(\mathrm{kg} / \mathrm{m}^{3} /\right.$ day $)$ \\
\hline$S T C$ & Specific thermal consumption $\left(\mathrm{kWh} / \mathrm{m}^{3}\right)$ \\
\hline$G O R$ & Gain Output Ratio \\
\hline$\theta$ & Incidence angle $\left({ }^{\circ}\right)$ \\
\hline$\eta_{o p t}$ & Optical efficiency (\%) \\
\hline$G_{k}$ & Global irradiation over tilted plane $\left(\mathrm{W} / \mathrm{m}^{2}\right)$ \\
\hline$T_{a m b}$ & Ambient temperature $\left({ }^{\circ} \mathrm{C}\right)$ \\
\hline$\dot{m}$ & Mass flow rate through the solar collector $(\mathrm{kg} / \mathrm{s})$ \\
\hline$T_{c o l}$ & Average between the inlet and outlet temperatures of the collector $\left({ }^{\circ} \mathrm{C}\right)$ \\
\hline$T_{i n}$ & Inlet water temperature in the solar collector $\left({ }^{\circ} \mathrm{C}\right)$ \\
\hline$T_{\text {out }}$ & Outlet water temperature in the solar collector $\left({ }^{\circ} \mathrm{C}\right)$ \\
\hline$K_{\tau \alpha}$ & Incident angle modifier \\
\hline$A_{a}$ & Aperture area of the collector $\left(\mathrm{m}^{2}\right)$ \\
\hline$C_{B}$ & Approximate cost of equipment (USD\$) \\
\hline$C_{A}$ & Known cost of equipment (USD\$) \\
\hline$S_{B} / S_{A}$ & Ratio known as the size factor \\
\hline$n$ & Size factor's exponent \\
\hline
\end{tabular}




\begin{tabular}{|c|c|}
\hline SCOW & Simplified Cost of Water (\$USD/m³) \\
\hline$M_{W}$ & Annual volume of water produced $\left(\mathrm{m}^{3}\right)$ \\
\hline$C_{F}$ & Annual fixed costs (\$USD) \\
\hline$C_{v}$ & Operating cost (\$USD) \\
\hline$I_{o}$ & Initial capital investment (\$USD) \\
\hline$\alpha$ & Amortization factor \\
\hline$i$ & Discount rate \\
\hline$t$ & Depreciation period (year) \\
\hline$C_{\text {consumables }}$ & Consumables costs (\$USD) \\
\hline$C_{\text {staff }}$ & Staff costs (\$USD) \\
\hline$C_{\text {maintenance }}$ & Maintenance costs (\$USD) \\
\hline$P_{e}$ & Total electric power consumed by the MED plant $(\mathrm{kW})$ \\
\hline$N_{\text {col_series }}$ & Number of collectors in series in a row \\
\hline$N_{\text {rows }}$ & Number of rows \\
\hline$N_{\text {total }}$ & Total number of collectors \\
\hline$A_{T}$ & Total aperture area $\left(\mathrm{m}^{2}\right)$ \\
\hline
\end{tabular}

\section{$41 \quad$ 1. Introduction}

42 Water is a vital resource for both human and economic development, so it is not surprising

43 that the absence or scarcity of water resources is directly related to poverty. Humanity faces

44 a water scarcity problem that grows in a sustained and almost exponential way. According to

45 the World Health Organization (WHO), 844 million people do not have easy access to an

46 improved source of drinking water; furthermore, this number exceeds two billion people if

47 this includes the access to enough water volume (WHO and UNICEF, 2017). This problem 
48 is related to governments and institutions around the world, so there are national policies in

49 many countries which aim to achieve universal access to safe water. Two-thirds of the 94

50 countries of the United Nations recognize drinking water and hygiene services as a universal

51 human right and $80 \%$ of them have approved national policies in this regard. However, only

52 a quarter of them are carried out as they were established. Despite the remarkable efforts

53 being made worldwide in the field of water, the United Nations institution highlights the

54 fundamental need to increase investment, build human capital and obtain reliable data on

55 which to base global actions (GLAAS Report, 2014).

56 Atacama Desert, which is considered the most arid one in the world, has annually less than

$5710 \mathrm{~mm}$ of precipitation per year, presenting isolated areas that only have water coming from

58 rivers and groundwater. Nevertheless, these waters have in many cases a high content of

59 salts, arsenic and boron and, therefore, they are neither suitable for human consumption nor

60 for agricultural and aviculture purposes. This fact limits the development of many locations

61 in the region which only economic resources are selling agricultural products (Bundschuh et

62 al., 2012).

63 The presence of arsenic and heavy metals in the environment is a very acute problem in Latin

64 America (Bundschuh et al., 2010). Arsenic is highly toxic in its inorganic form and its

65 presence is mainly associated with altiplanic quaternary volcanism in the north of Chile.

66 According to the WHO-2016 (WHO, 2016) over 226 million people worldwide are estimated

67 to be drinking contaminated water, with an arsenic contaminant level above the $10 \mu \mathrm{g} / \mathrm{L}$ that

68 WHO establishes as a maximum. This situation can lead to chronic arsenic poisoning

69 (arsenicosis) of which skin lesions and skin cancer are the most characteristic effects

70 (Bhattacharjeea, 2013; Hong-Jie et al., 2014; López et al., 2012; Yunus et al., 2011).

71 According to the FONDECYT REGULAR 2011 project results, (FONDECYT REGULAR 
72 2011, "An evaluation of the distribution, mobility and bioavailability of the arsenic present

73 in soil and water in the Valley of Camarones, Chile: study of the levels of transference and

74 the accumulation of arsenical species in native plants and crops" Code: 1120881) where an

75 evaluation of the distribution and mobility of the arsenic present in soil and water was

76 performed, the water in the Arica and Parinacota Region presents different levels of arsenic,

77 both $\mathrm{As}(\mathrm{III})$ and $\mathrm{As}(\mathrm{V})$ species. The highest levels, more than 100 times higher than the levels

78 established by national and international institutions (Decreto Supremo 143/2009; Decreto

79 Supremo 144/2019; Directive 98/83/EC) are found in the Valley of Camarones. This problem

80 presents a difficult solution, as the arsenic cannot be easily destroyed and can only be

81 converted into different forms or transformed into insoluble compounds in combination with

82 other elements, such as iron (Choong et al., 2007).

83 One of the most affected areas in the valley of Camarones is the Taltape community, where

84 the inhabitants economy is mainly based on the exploitation of small agricultural estates,

85 with low-valuable products such as alfalfa, and the production of meat, milk and cheese

86 (mainly from cattle and goats). Due to the above mentioned situation, the generated products

87 contain As and, consequently, these cannot be introduced in the legal markets, which affects

88 the local development. For this reason, there is an important need to solve the water quality

89 problem in a sustainable way so that this location can be established as an agricultural oasis

90 in the middle of the desert, which would allow growing higher added value products such as

91 tomato and/or onion, among others.

92 One of the possible solutions to face up this problem is desalination. Reverse osmosis

93 (RO), multi-stage flash (MSF) and multi-effect distillation (MED) account for more than

$9494 \%$ of the worldwide desalination capacity $(\mathrm{Li}, 2013)$. The only desalination technology

95 implemented in the Arica and Parinacota Region so far has been RO. However, in spite of 
96 its excellent salt rejection characteristics, it presents very low boron and As (III) removal

97 efficiencies (Abejón et al., 2015; Bick et al., 2005; Hilal et al., 2011; Kang et al., 2000;

98 Ning, 2002; Öztürk et al., 2008; Wang et al., 2016). Apart from that, further problems such

99 as red algae blooms make RO desalination more disadvantageous versus the thermal

100 desalination technologies, which are more robust under these particular conditions. The

101 thermal processes also have some other advantages with respect to membrane processes,

102 like: easier operation and maintenance that make their installation possible in countries with

103 lack of experienced personnel, higher purity of the produced distillate and capability to deal

104 with harsh high temperature and salinity feed waters or even with contamination

105 (Palenzuela et al., 2014). Among thermal desalination plants, MED technology is the

106 preferred choice due to its low top brine temperature, typically less than $70{ }^{\circ} \mathrm{C}$, and its low

107 specific energy consumption requirements (Yang and Lior, 2006). On the other hand, the

108 usual coincidence in many locations of fresh water shortage and high isolation levels make

109 the combination of MED processes with solar energy a perfect combination to tackle the

110 water scarcity problem in a sustainable way. Some countries of MENA region (as Qatar,

111 Morocco, etc) and South America (mainly Chile) are more and more promoting the use of

112 solar energy to meet its growing energy and fresh water demands (Darwish et al., 2013;

113 Mohtar and Darwish, 2013; Hanel and Escobar, 2013; Valenzuela et al., 2017).

114 In the context of a regional Chilean project (FIC Taltape project, BIP code 30158422-0), a

115 MED plant to treat brackish water containing As and Boron was installed in the Taltape

116 community. The plant has a fresh water production capacity of $10 \mathrm{~m}^{3} /$ day and is driven by

117 thermal energy from a biomass boiler. The electricity required is taken both from a 118 photovoltaic solar field and from a diesel generator (backup). The feasibility of the MED 119 process has been tested with large-scale fossil plants for many years, especially in the Gulf 
120 countries. However, there are not many solar MED units in operation. One of the solar MED

121 plants with more operation hours is located at the Plataforma Solar de Almería (PSA). This

122 MED unit presents a freshwater production capacity of $72 \mathrm{~m}^{3} /$ day and it is coupled to a static

123 solar field. Several research works have been published in the scientific literature, which

124 analyse the distillate production and the thermal efficiency of this plant at different operating

125 conditions (Fernández-Izquierdo et al., 2012; Palenzuela et al., 2016; Chorak et al., 2017).

126 The best operating conditions to maximize the distillate production found for this plant was

127 to work at the maximum outlet temperature from the solar field and maximum value of the

128 feed water flow rate in summer months and at minimum vapour temperature in the condenser

129 and maximum outlet temperature from the solar field in winter months (Chorak et al., 2017).

130 There is another solar MED plant located in Abu Dhabi, which is one of the first plants to be

131 installed (120 m³/day capacity) (El-Nashar and Ishii, 1985), although not much data have

132 been reported from its operation. Only one test campaign developed in this solar MED plant

133 has been published in the literature and it was focused on the validation of a steady-state

134 model (El-Nashar and Qamhiyeh, 1995). The results showed that the product water flow rate

135 increased from 4 to $7 \mathrm{~m}^{3} / \mathrm{h}$ with the increase in the heating water temperature and it remained

136 almost constant with the change in the heating water flow rate. On the other hand, it was

137 observed that the specific heat consumption increased from 40 to $50 \mathrm{kcal} / \mathrm{kg}$ distillate when

138 the heating water temperature rose from 65 to $75^{\circ} \mathrm{C}$. As far as the authors' knowledge, there

139 are no techno-economic studies in the scientific literature that address the use of MED plants

140 with solar energy to obtain treated water for agricultural purposes.

141 The goal of this study case is to carry out a techno-economic assessment of a MED plant with 142 eight effects to treat brackish water from Camarones River located in Taltape (Arica and 143 Parinacota Region, Chile), which presents high As and Boron content, for agricultural and 
144 domestic purposes. For the technical analysis, an initial characterization of the feed water 145 and the effluents from the MED plant (distillate and brine) obtained during several months

146 of operation, has been performed. Then, a design model of the MED plant has been developed

147 and implemented in Matlab with simulation purposes. The plant is currently coupled to a

148 biomass boiler that provides the thermal energy required to operate the MED plant and to a

149 photovoltaic solar field and a diesel generator (as back-up) for the electricity requirements of

150 the distillation plant. The biomass boiler will be replaced by a thermal static solar field that

151 is sized in the present work as the main element to provide the thermal energy to the MED

152 plant, using the boiler as a backup when the solar energy is not available. Moreover, the

153 thermal static solar field has been designed and a model of this field that predicts the hourly

154 thermal power provided to the MED unit along the year has been developed using a typical

155 meteorological year. This model also determines the annual solar fraction, which is the

156 relation between the amount of energy obtained through the used solar technology and the

157 total annual energy required by the process. Finally, the annual freshwater production has

158 been determined and an economic analysis has been performed including the plant scale in

159 order to provide different amounts of fresh water up to $5,000 \mathrm{~m}^{3} /$ day.

160 2. Description of the system installed

161 2.1. Multi-Effect Distillation plant

162 The MED pilot plant of Taltape (see the flow diagram in Fig. 1), manufactured and delivered

163 by INERCO Tratamiento de Aguas S.A. (Madrid, Spain) in 2016 consists of simultaneous

164 evaporation processes of brackish water and subsequent vapour condensation at decreasing

165 pressures and temperatures from the first effect to the last one. This plant has eight effects

166 and each one consists in a submerged tube heat exchanger provided by AURUM Processes

167 Company (Murcia, Spain), through which steam flows as thermal energy source. The 
168 brackish water comes from the Camarones River and is firstly collected in a reserve tank $169\left(\mathrm{RT} 1,10 \mathrm{~m}^{3}\right)$ and pre-treated by microfiltration $(25 \mu \mathrm{m}$ cartridge filter $)$ before starting the 170 distillation process. From RT1, water is pumped to the MED plant $\left(24.3 \mathrm{~m}^{3} / \mathrm{h}\right)$. Among the 171 total flow rate, $23 \mathrm{~m}^{3} / \mathrm{h}$ are pumped to the end condenser for refrigeration and $0.8 \mathrm{~m}^{3} / \mathrm{h}$ of 172 feed water (pre-treated in a sand filter) is sent to the first effect of the MED plant after flowing 173 through the preheaters. The remaining flow rate $\left(0.5 \mathrm{~m}^{3} / \mathrm{h}\right)$ is used to cool down the vacuum 174 pump (VP1) working on the brackish water circuit (see Fig. 1). Another vacuum pump (VP2) 175 is cooled by the distillate water circuit. These two vacuum pumps are used to discharge the 176 brine and the distillate outside the plant, also providing the necessary vacuum conditions in 177 the process.

178 The first effect is heated with hot water coming from a biomass boiler $\left(20 \mathrm{~m}^{3} / \mathrm{h}, 70^{\circ} \mathrm{C}\right)$. The 179 brackish water enters the first effect passing through all the pre-heaters and part of it is 180 evaporated generating steam that is later used as the thermal energy source for the following 181 effect. The brackish water that has not been evaporated in the first effect (called brine), goes 182 to the second effect where there is partially evaporated by the steam entering the second 183 effect that transfers its latent heat to the brine. The steam is then condensed, being the first 184 distillate of the process. In order to maximize the energetic efficiency of the plant, this 185 condensate enters the next effect along with the steam that has been already produced in the 186 previous effect. The same process is repeated for the rest of effects.

187 The extraction of the distillate and brine is obtained by means of two vacuum pumps (VP 1 188 and 2), one for each circuit. In order to facilitate the extraction of both streams, two small 189 reservoir deposits $\left(0.2 \mathrm{~m}^{3}\right)$ were installed, one for each stream. When these reservoirs 190 accumulate enough volume, the distillate/concentrate is extracted by the corresponding pump 191 to another reservoir tank (RT 2, $\left.5 \mathrm{~m}^{3}\right)$. Later, in a third reservoir tank (RT3, $\left.10 \mathrm{~m}^{3}\right)$ the 
192 produced distillate water is post-treated to achieve irrigation and domestic water

193 characteristics (post-treatment). Finally, the brine is mixed with the outlet of the cooling

194 stream and returned to the Camarones River (see Fig. 1). Notice that the brine represents only

$1951-2 \%$ of the total waste volume, so the mixture that finally is spilt into the river does not

196 damage the ecosystem.

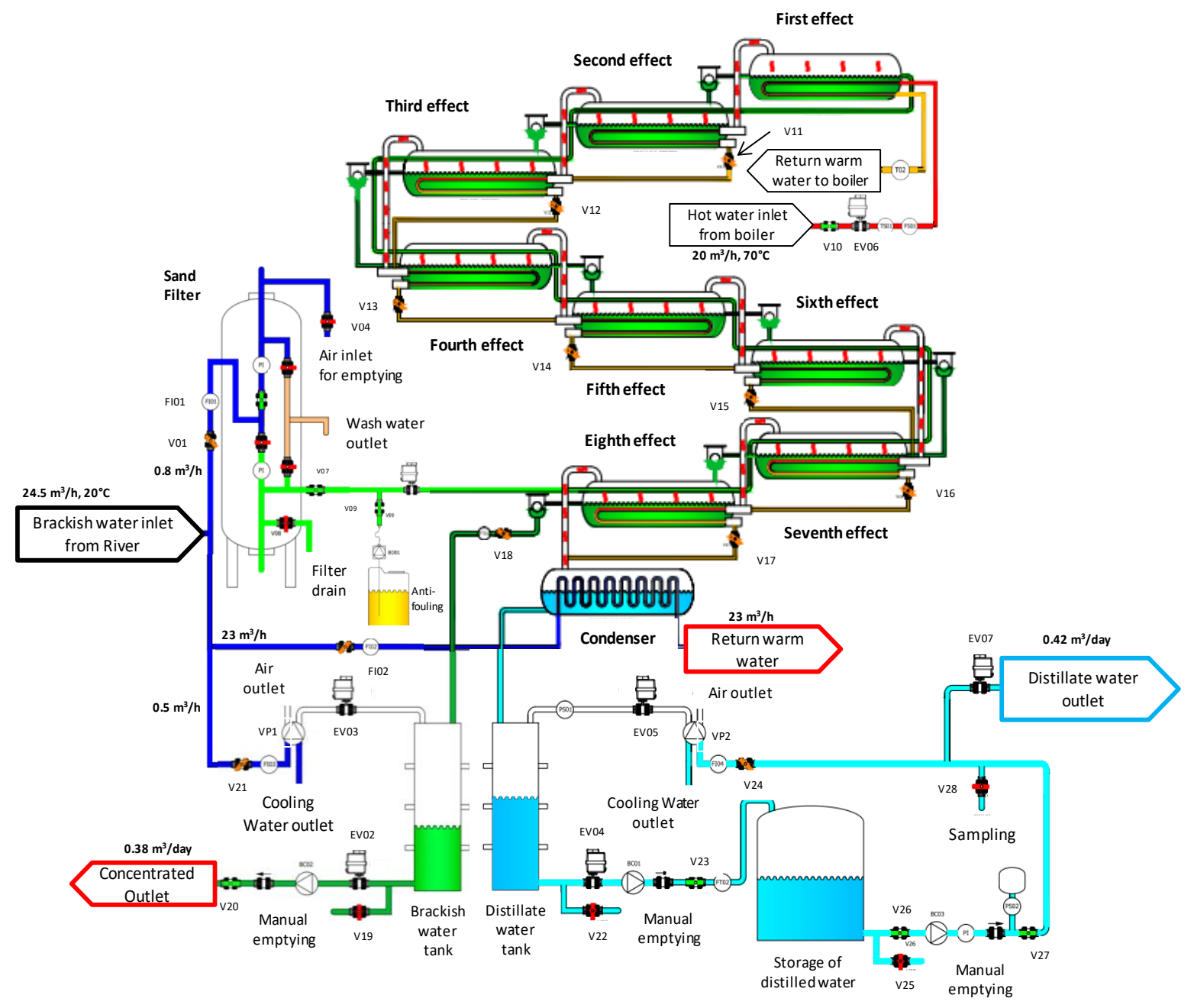

Fig. 1. Scheme of MED system

\section{$198 \quad 2.2$ Energy supply systems}

199 The energy supply, electricity and thermal energy, for the MED plant is done by a

200 photovoltaic (PV) solar field and a diesel generator for the electricity requirements and by a 
201 biomass boiler for the thermal energy requirements. Fig. 2 shows a scheme of how the 202 installed MED unit is coupled to the mentioned energy supply systems. The PV solar field 203 consists in $10 \mathrm{PV}$ panels of polycrystalline silicon. The panels are tilted $19^{\circ}$ (local latitude).

204 The dimensions of each panel are 1,640x990x40 mm with 60 cells per panel. The total surface 205 is $15.8 \mathrm{~m}^{2}$ with $3.1 \mathrm{~kW}_{\mathrm{p}}\left(\mathrm{P}_{\max }\right.$ per panel $\left.=320 \mathrm{~W}\right)$. Four stationary batteries of Lithium $12 \mathrm{~V}$ $206250 \mathrm{AH}$ are available in the system. The Diesel generator was provided by VIELCO 207 Company, KIPOR PRO-X model KDS28SS3. It has an output of $21.3 \mathrm{kVA}(17 \mathrm{~kW})$ and 208 works at $1500 \mathrm{rpm}$ with $\cos \Phi=0.8$, at 230 or $400 \mathrm{~V}$. The necessary electricity for the whole 209 system (MED production of $10 \mathrm{~m}^{3} /$ day) is considered as $12 \mathrm{~kW}$ corresponding to: (i) MED 210 plant (5 kW), (ii) 4 pumps outside (3 x $2 \mathrm{~kW}$ and $1 \times 0.5 \mathrm{~kW})$ and (iii) the boiler $(0.5 \mathrm{~kW})$.

211 The electricity is provided only by the PV system during the sun hours and diesel generator 212 is used as backup during the night.

213 The biomass boiler was provided by Nueva Energía, Biocalora serie 2000 model B-MAX 50.

214 It has a rated thermal input of $50 \mathrm{~kW}$ and the heating surface is between $600-900 \mathrm{~m}^{2}$, being 215 fuel type pellets DIN $\varnothing 6 \mathrm{~mm} \div \mathrm{L}=5-30 \mathrm{~mm}$. The boiler performance is $90.1 \%$ with 2 bars 216 of pressure max and $90{ }^{\circ} \mathrm{C}$ of maximum operation temperature. 


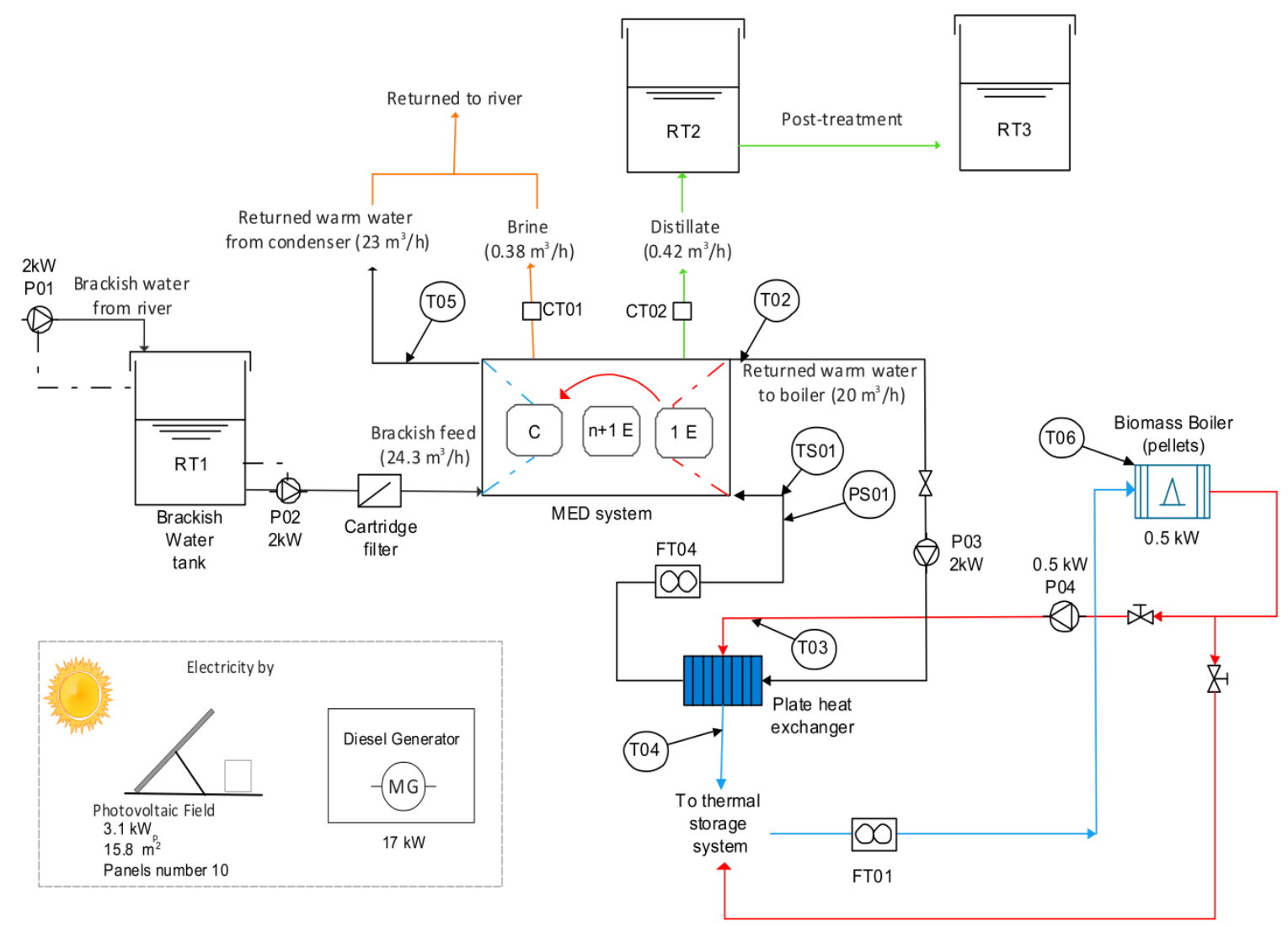

Fig. 2. General scheme of system

218 3. Techno-economic assessment

\section{3.1 MED's effluents characterization}

220 The characteristics of the brackish feed water from Camarones River and the effluents

221 obtained from MED operation (brine and distillate) were gathered during several months.

222 Average values are shown in Table 1 (the parameters of the waste stream returned to

223 Camarones River were calculated by mass balance).

224 In order to determine the percentage of solutes remaining in the brine solution, the retention

225 percentages are determined by Eq. 1. The results are shown in Table 1:

$$
R(\%)=\frac{C_{B F W}-C_{D}}{C_{B F W}} \cdot 100
$$

226 where $C_{B F W}$ is the concentration of the corresponding parameter ( $\mathrm{As}, \mathrm{B}, \mathrm{Cd}, \mathrm{Cu}$, etc.) in the

227 brackish feed $(\mathrm{mg} / \mathrm{L})$ water and $C_{D}$ the same one in the distillate water $(\mathrm{mg} / \mathrm{L})$. 
228 Notice that all the retention percentages obtained were higher than $90 \%$ and more specifically

229 B and As, that were removed in $95 \%$ and $99 \%$ respectively. As explained above, these are

230 especially toxic elements for plants and humans, respectively.

231 Table 1

232 Characterization of brackish feed water, brine, distillate and waste stream

\begin{tabular}{lcccccc}
\cline { 2 - 6 } & Units & $\begin{array}{c}\text { Brackish feed } \\
\text { water }\end{array}$ & Brine & Distillate & R (\%) & $\begin{array}{c}\text { Waste stream } \\
\text { (refrigeration }+ \text { brine) }\end{array}$ \\
\hline Flow & $\mathrm{m} / \mathrm{h}$ & 0.80 & 0.38 & 0.42 & -- & 23.38 \\
\hline $\begin{array}{l}\text { Total Disolved } \\
\text { Solids }(\mathrm{TDS})\end{array}$ & $\mathrm{mg} / \mathrm{L}$ & 1,900 & 3,980 & 19.0 & 99 & 1,930 \\
\hline Conductivity & $\mathrm{MS} / \mathrm{cm}$ & 2,600 & 5,250 & 200 & 92 & 2,640 \\
\hline Arsenic $\left(\mathrm{As}_{\text {total }}\right)$ & $\mathrm{mg} / \mathrm{L}$ & 0.60 & 1.26 & 0.006 & 99 & 0.61 \\
\hline Boron $\left(\mathrm{B}_{\text {total }}\right)$ & $\mathrm{mg} / \mathrm{L}$ & 15.0 & 30.8 & 0.75 & 95 & 15.2 \\
\hline Cadmium $\left(\mathrm{Cd}^{+2}\right)$ & $\mathrm{mg} / \mathrm{L}$ & 0.05 & 0.10 & 0.004 & 92 & 0.051 \\
\hline Calcium $\left(\mathrm{Ca}^{+2}\right)$ & $\mathrm{mg} / \mathrm{L}$ & 210 & 430 & 8.4 & 96 & 213 \\
\hline Chlorides $\left(\mathrm{Cl}^{-}\right)$ & $\mathrm{mg} / \mathrm{L}$ & 700 & 1,420 & 49.0 & 93 & 711 \\
\hline Copper $\left(\mathrm{Cu}^{+2}\right)$ & $\mathrm{mg} / \mathrm{L}$ & 0.05 & 0.10 & 0.001 & 99 & 0.051 \\
\hline Iron $\left(\mathrm{Fe}_{\text {total }}\right)$ & $\mathrm{mg} / \mathrm{L}$ & 0.20 & 0.40 & 0.016 & 92 & 0.20 \\
\hline Magnesium $\left(\mathrm{Mg}^{2+}\right)$ & $\mathrm{mg} / \mathrm{L}$ & 25.0 & 52.0 & 0.25 & 99 & 25.4 \\
\hline Manganese $\left(\mathrm{Mn}^{+2}\right)$ & $\mathrm{mg} / \mathrm{L}$ & 0.13 & 0.27 & 0.003 & 98 & 0.13 \\
\hline Plumb $\left(\mathrm{Pb}^{+2}\right)$ & $\mathrm{mg} / \mathrm{L}$ & 0.03 & 0.06 & 0.003 & 91 & 0.030 \\
\hline Potassium $\left(\mathrm{K}^{+}\right)$ & $\mathrm{mg} / \mathrm{L}$ & 35.0 & 72.0 & 1.8 & 95 & 35.6 \\
\hline Selenium $\left(\mathrm{Se}_{\text {total }}\right)$ & $\mathrm{mg} / \mathrm{L}$ & 0.20 & 0.41 & 0.01 & 95 & 0.20 \\
\hline Sodium $\left(\mathrm{Na}^{+}\right)$ & $\mathrm{mg} / \mathrm{L}$ & 200 & 420 & 2.0 & 99 & 203 \\
\hline Sulphates $\left(\mathrm{SO}_{4}^{2-}\right)$ & $\mathrm{mg} / \mathrm{L}$ & 310 & 625 & 24.8 & 92 & 315 \\
\hline Zinc $\left(\mathrm{Zn}^{+2}\right)$ & $\mathrm{mg} / \mathrm{L}$ & 0.30 & 0.62 & 0.006 & 98 & 0.31 \\
\hline
\end{tabular}

234 3.2. Modelling and scale up of the solar water treatment system

$235 \quad$ 3.2.1 MED plant

236 Taking the MED pilot plant located at the Taltape community as reference (8 stages, 10

$237 \mathrm{~m}^{3} /$ day), a scale-up has been carried out for higher capacities, from $10 \mathrm{~m}^{3} /$ day to 5,000

$238 \mathrm{~m}^{3} /$ day, in order to perform the economical assessment later. For this purpose, a design model 
239 of a MED plant with the same configuration as the one implemented in Taltape has been

240 developed and implemented in Matlab. The MED model is based in the one published in

241 (Palenzuela et al., 2014) but particularized for this study. In this model, unlike that the one

242 described in our previous work, equal area in all effects was considered. For the computation

243 of the model, an iteration loop was implemented in the Matlab software that starts with the

244 temperature profile and continues until a convergence criterion is achieved. The convergence

245 criterion of the model should have a maximum difference in effect areas of $1 \cdot 10^{-4}$ in order to

246 achieve a good accuracy.

247 Firstly, the temperature difference between effects is obtained by the following equation:

$$
\Delta T_{e f f, i}=\frac{T_{v, 1}-T_{v, N}}{N-1}
$$

248 where $\boldsymbol{N}$ is the number of stages, $\boldsymbol{T}_{\boldsymbol{v}, \mathbf{1}}$ is the vapor temperature generated in the $1_{\text {st }}$ effect and

$249 \boldsymbol{T}_{\boldsymbol{v}, \boldsymbol{N}}$ is the vapor temperature generated in the last effect. In all cases, $\boldsymbol{N}$ has been established 250 as 8 stages, $\boldsymbol{T}_{\boldsymbol{v}, \mathbf{1}}$ as $70^{\circ} \mathrm{C}$ and $\boldsymbol{T}_{\boldsymbol{v}, \boldsymbol{N}}$ as $35^{\circ} \mathrm{C}$.

251 On the other hand, the area of each evaporator $\left(\boldsymbol{A}_{\boldsymbol{e} i}\right)$ is defined by the heat transfer equation.

252 For the sake of simplicity, all the equations shown correspond to the first effect but can be 253 extrapolated to the rest of effects:

$$
Q_{s}=A_{e 1} U_{e 1}\left(T_{s}-T_{v 1}\right)=M_{s} \lambda_{s}
$$

254 where $\boldsymbol{Q}_{\boldsymbol{s}}$ is the heat transfer rate provided to the first effect, $\boldsymbol{T}_{\boldsymbol{s}}$ the temperature of the heating 255 energy source supplied to the first effect of the MED plant, $\boldsymbol{T}_{\boldsymbol{v} \mathbf{1}}$ is the temperature of the 256 vapor generated inside the first effect, $\boldsymbol{M}_{\boldsymbol{s}}$ is the steam mass flow rate supplied as the heating 257 energy source to the first effect, $\lambda_{s}$ is the change in enthalpy related to the condensation of 258 the steam supplied to the first effect, and $\boldsymbol{U}_{\boldsymbol{e} \mathbf{1}}$ is the overall heat transfer coefficient of the 
259 first evaporator. Notice that, although the heat transfer source provided to the first effect in 260 the MED pilot plant of Taltape is hot water, for the high scale MED plants, steam has been 261 considered as the energy source to match the commercial plants worldwide.

262 The overall heat transfer coefficient is determined by the correlation proposed by El263 Dessouky and Ettouney (2002):

$$
U_{e 1}=1.9695+1.2057 \cdot 10^{-2} T_{v 1}-8.5989 \cdot 10^{-5} T_{v 1}^{2}+2.5651 \cdot 10^{-7} T_{v 1}^{3}
$$

264 The ratio between the sum of all the evaporator areas to the distillate production is called 265 specific area $(\boldsymbol{s} \boldsymbol{A})$ and it is a characteristic parameter that gives an idea of the size of the MED 266 plants.

267 The mass flow rates of distillate and brine together with the temperatures of all the streams 268 are determined by mass and energy balances in all the effects:

$$
M_{f}=M_{g b, 1}+M_{b, 1}
$$

269 where $\boldsymbol{M}_{\boldsymbol{g b}, \mathbf{1}}$ is the total vapor generated that, in turn, is converted to distillate when it 270 condenses in the following effect, $\boldsymbol{M}_{\boldsymbol{f}}$ is the feedwater mass flow rate and $\boldsymbol{M}_{\boldsymbol{b}, \mathbf{1}}$ is the brine

271 flow rate that remain from the evaporation taking place in the first effect.

$$
M_{g b, 1} \lambda_{g b, 1}=M_{s} \lambda_{s}-M_{f} C_{p}\left(T_{v 1}-T_{f}\right)
$$

272 where $\lambda_{\boldsymbol{g} \boldsymbol{b}, \mathbf{1}}$ the latent heat of vaporization at $\boldsymbol{T}_{\boldsymbol{v} \mathbf{1}}, \boldsymbol{C}_{\boldsymbol{p}}$ is the specific heat and $\boldsymbol{T}_{\boldsymbol{f}}$ the 273 temperature of the feedwater that reaches the first effect of the MED plant.

274 One of the parameters that evaluates the performance of the MED plant is the Recovery Ratio $275(\boldsymbol{R} \boldsymbol{R})$, which is defined as the ratio of the total distillate obtained from the plant $\left(\boldsymbol{M}_{\text {prod }}\right)$ to 276 the feed water flow rate $\left(\boldsymbol{M}_{\boldsymbol{f}}\right)$ : 


$$
R R=\frac{M_{\text {prod }}}{M_{f}}
$$

277 This parameter has been established as an input in the model of the MED plant and a value

278 of $50 \%$ has been considered in all cases (this is a fair value when low salinity feed water is

279 being treated by an MED plant).

280 Another performance parameter is the specific thermal consumption (STC), which is defined

281 as the thermal energy supplied to the plant $\left(\boldsymbol{Q}_{\boldsymbol{s}}\right)$ for the total distillate obtained from the plant:

$$
S T C=\frac{Q_{s}}{M_{\text {prod }}}
$$

282 The third performance parameter of this kind of plants is the Gain Output Ratio (GOR) which

283 is defined as the mass flow rate of distillate produced per consumed heating steam rate:

$$
G O R=\frac{M_{\text {prod }}}{M_{s}}
$$

\section{$285 \quad 3.2 .2$. Thermal solar field}

286 The thermal solar field has been sized for all the sizes of the MED plant (from $10 \mathrm{~m}^{3} /$ day to

$2875,000 \mathrm{~m}^{3} /$ day) and the results in terms of total aperture area have been used in the economic

288 assessment. It has been considered as a solar field composed by evacuated tube collectors

289 (ETC) to supply the thermal energy required by the MED plant, since they are the ones with

290 the highest efficiency among the static solar collectors. The selected collector is from the

291 company sunflower renewable energy Co. (model SF-BF305818) whose technical

292 characteristics are shown in Table 2.

293 Table 2

294 Characteristics of the ETC (results of EN 12975 test results)

Aperture area: $2.83 \mathrm{~m}^{2}$ 


\begin{tabular}{|c|c|}
\hline \multirow[t]{7}{*}{ Longitudinal incidence angle modifier } & $\theta_{L}=10^{\circ}: 1.00$ \\
\hline & $\theta_{L}=20^{\circ}: 1.00$ \\
\hline & $\theta_{L}=30^{\circ}: 0.99$ \\
\hline & $\theta_{L}=40^{\circ}: 0.97$ \\
\hline & $\theta_{L}=50^{\circ}: 0.92$ \\
\hline & $\theta_{L}=60^{\circ}: 0.84$ \\
\hline & $\theta_{L}=70^{\circ}: 0.68$ \\
\hline \multirow[t]{7}{*}{ Tangential incidence angle modifier } & $\theta_{T}=10^{\circ}: 1.04$ \\
\hline & $\theta_{T}=20^{\circ}: 1.09$ \\
\hline & $\theta_{T}=30^{\circ}: 1.23$ \\
\hline & $\theta_{T}=40^{\circ}: 1.38$ \\
\hline & $\theta_{T}=50^{\circ}: 1.78$ \\
\hline & $\theta_{T}=60^{\circ}: 1.82$ \\
\hline & $\theta_{T}=70^{\circ}: 2.08$ \\
\hline \multirow[t]{3}{*}{ Efficiency parameters } & $\eta_{\text {opt }}: 0.64$ \\
\hline & $c_{1}: 1.494 \mathrm{~W} / \mathrm{K} \cdot \mathrm{m}^{2}$ \\
\hline & $c_{2}: 0.012 \mathrm{~W} / \mathrm{K}^{2} \cdot \mathrm{m}^{2}$ \\
\hline
\end{tabular}

Flow rate: $0.020 \mathrm{~kg} / \mathrm{s} \cdot \mathrm{m}^{2}$ 
$296 \boldsymbol{\eta}_{\text {opt }}, \boldsymbol{c}_{\mathbf{1}}$ and $\boldsymbol{c}_{\mathbf{2}}$ are the optical efficiency and the coefficients accounting for thermal losses, 297 respectively.

298 The collectors are orientated to the North and with a tilt angle equal to the local latitude. The

299 location of Taltape has the following geographical coordinates: lat. $18.99^{\circ} \mathrm{S}$, long. $69.77^{\circ}$

300 W. For the size of the solar field, a design point (specific date, including month, day and 301 time) is firstly selected from a typical meteorological year (TMY) that has been obtained 302 with Meteonorm software for the specific location. The design point selected has been $19^{\text {th }}$

303 of June at solar noon (this time corresponds to sun zenith and presents greater stability of the

304 direct solar irradiation) due to the good weather conditions, which can lead to higher solar 305 operation hours of the water treatment plant. Also, a solar multiple of 2 has been considered 306 in order to have an annual solar contribution close to 50\% (it means higher hours of solar 307 operation for the water treatment system).

308 Table 3 shows the monthly data of global irradiation over tilted plane $\left(\mathrm{G}_{\mathrm{k}}\right)$ and ambient 309 temperature $\left(\mathrm{T}_{\mathrm{amb}}\right)$

310 Table 3

311 Data of irradiation and ambient temperature of a TMY in Taltape, Arica

\begin{tabular}{ccc}
\hline Month & $\mathrm{G}_{\mathrm{k}}\left[\mathrm{kWh} / \mathrm{m}^{2}\right]$ & $\mathrm{T}_{\mathrm{amb}}\left[{ }^{\circ} \mathrm{C}\right]$ \\
\hline January & 190 & 19.9 \\
\hline February & 173 & 20.2 \\
\hline March & 188 & 19.4 \\
\hline April & 154 & 16.9 \\
\hline May & 136 & 14.2 \\
\hline June & 110 & 12.4 \\
\hline
\end{tabular}




\begin{tabular}{ccc}
\hline July & 119 & 11.9 \\
\hline August & 137 & 11.9 \\
\hline September & 154 & 12.6 \\
\hline October & 180 & 14.3 \\
\hline November & 186 & 16.1 \\
\hline December & 186 & 18.2 \\
\hline
\end{tabular}

313 The global irradiation data has been normalized with the actual measurement of the yearly

314 global irradiation over a tilted plane $\left(\mathrm{G}_{\mathrm{k}}, 2,110 \mathrm{kWh} / \mathrm{m}^{2} \cdot \mathrm{y}\right)$ obtained from a radiometric

315 measuring solar station located close to the selected location.

316 The design of the solar field is carried out by firstly determining the number of collectors in

317 series in a row and secondly the number of rows in parallel.

318 On one hand, the number of collectors in series in a row is determined by the ratio between

319 the temperature increase required in a row and the temperature step of an individual solar

320 collector. The outlet temperature reached at the outlet of the collector is determined by the

321 efficiency equation of the collector:

322

$$
\eta_{i}=\frac{\dot{m} C_{p}\left(T_{o u t}-T_{\text {in }}\right)}{G_{k} A_{a}}=\eta_{o p t} K_{\tau \alpha}-c_{1}\left[\frac{\left(T_{c o l}-T_{a m b}\right)}{G_{k}}\right]-c_{2}\left[\frac{\left(T_{c o l}-T_{a m b}\right)^{2}}{G_{k}}\right]
$$

324 where $\boldsymbol{m}$ is the heat transfer fluid (i.e. water) mass flow rate through the solar collector; $\boldsymbol{C}_{\boldsymbol{p}}$ 325 is the average heat capacity of the heat transfer fluid; $\boldsymbol{T}_{\boldsymbol{c o l}}$ is the average between the inlet 326 and outlet temperatures of the collector; $\boldsymbol{T}_{\boldsymbol{i n}}$ and $\boldsymbol{T}_{\text {out }}$ are the inlet and outlet temperatures in 
327 the solar collector, respectively; $\boldsymbol{G}_{\boldsymbol{k}}$ is the global solar irradiance on tilted plane in W/m $2 \mathrm{~m}^{2}, \boldsymbol{A}_{\boldsymbol{a}}$ 328 is the aperture area of the collector and $\boldsymbol{K}_{\boldsymbol{\tau} \boldsymbol{\alpha}}$ is the incident angle modifier, which is 329 determined as the product between the longitudinal and tangential incident angle modifiers 330 (see Table 2):

$$
K_{\tau \alpha}=K_{\tau \alpha}(T) \cdot K_{\tau \alpha}(L)
$$

331 Considering the operational temperature of the MED plant between $65^{\circ} \mathrm{C}$ and $75^{\circ} \mathrm{C}$, a 332 temperature increase in the solar field from $75^{\circ} \mathrm{C}$ to $85^{\circ} \mathrm{C}$ has been established for the 333 calculation.

334 On the other hand, the number of rows is determined as the ratio between the thermal power 335 to be supplied by the solar field (that is the thermal power required by the MED plant, which 336 is defined by the specific thermal consumption and distillate production of the plant) and the 337 thermal power supplied by one individual row. This last one is determined from the thermal 338 power supplied by one collector (according to equation 10), multiplied by the number of 339 collectors connected in series. The product of the number of collectors connected in series 340 and the number of rows gives the total number of collectors required by the solar field that 341 multiplied by the aperture area of one collector, leads to the total area of the solar field.

342 Finally, an annual simulation model of the dimensioned solar field developed by the authors 343 (Andrés-Mañas et al., 2017) has been used to determine the hours of operation of the water 344 treatment plant with solar energy for all MED plant capacities. The model determines the 345 thermal power supplied by the solar field every hour by an iteration loop that recalculates the 346 flow rate through the solar field as a function of the outlet temperature reached. The hours of 347 solar operation are considered when the hourly power provided by the solar field is higher 348 than the $50 \%$ of the MED thermal load. The model also gives the solar fraction, which is 
349 defined as the relation between the amount of energy obtained through the solar technology

350 used and the total annual energy required by the process. The amount of energy obtained

351 through the solar technology is determined as the sum of the thermal power provided in each

352 interval multiplied by the time interval, and the total energy required by the process as the

353 thermal power multiplied by the hours of operation and by the total days in the year. Also,

354 the model gives the annual fresh water produced by the MED plant with the thermal energy

355 provided by the solar field. The definition of Gain Output Ratio has been used for this

356 purpose.

$357 \quad 3.3$ Economical assessment

358 The economical assessment was done using the data obtained from the plant installed at

359 Taltape $\left(10 \mathrm{~m}^{3} /\right.$ day $)$, which includes actual data about the system implementation and

360 operation. The plant scaling up was carried out up to $5000 \mathrm{~m}^{3} /$ day, which is considered the

361 water production needed to supply the nearest city located at the same Chilean region as

362 Taltape, named Arica, with approximately 200,000 inhabitants. For the evaluation of the

363 scaling up effect, 10, 200, 500, 1,000, 2,500 and 5,000 $\mathrm{m}^{3} /$ day have been taken as the

364 production capacities. In addition, 350 operating days per year were taken into account,

365 corresponding to a water production of $3.5 \cdot 10^{3} \mathrm{~m}^{3} / \mathrm{yr}$ for the smallest MED plant and

$3661.75 \cdot 10^{6} \mathrm{~m}^{3} / \mathrm{yr}$ for the biggest MED plant considering a 24/7 operating regime. According to

367 (Papapetrou et al., 2017), it is necessary to define boundary conditions for the cost

368 calculation. In this work, post-treatment of distilled water is excluded as well as water

369 distribution, laboratory for quality control and distillation plant decommissioning at the end-

370 of-life. Chemical costs included in the calculation were (industrial-grade prices obtained

371 from Chilean companies): pellets for biomass boiler 0.17 USD $\$ / \mathrm{kg}$-price provided by

372 PROENERGY S.L. (VIII region, Chile); Diesel for generator 0.63 USD\$/L -price provided 
373 by PETRONOR S.L. (XV region Chile); Oil and refrigerant for maintaining of generator 374 motor was 7.2 and 7.4 USD $\$ / L$, respectively -prices provided by SODIMAC S.L. (XV 375 region, Chile); anti-fouling model GMP 670 was 8.7 USD\$/L -prices provided by GENESYS 376 MEMBRAM PRODUCTS (Metropolitan region, Chile)-.

377 For the scaling of the main equipment, the costs can be obtained by the Rule of Six Tenths 378 (Seider et al. 2004) if the cost of a similar item of different size or capacity is known. The 379 following equation, Eq. 12, expresses the rule of six-tenths:

$$
C_{B}=C_{A} \cdot\left(\frac{S_{B}}{S_{A}}\right)^{n}
$$

380 where $C_{B}$ represents the approximate cost (USD\$) of equipment having size $S_{B}\left(\mathrm{~kW}, \mathrm{Hp}, \mathrm{m}^{2}\right.$,

381 or whatever). $C_{A}$ is the known cost (USD\$) of equipment having a corresponding size $S_{A}$

382 (same units as $S_{B}$ ), and $\frac{S_{B}}{S_{A}}$ is the ratio known as the size factor, dimensionless. The size 383 factor's exponent, "n", depends on the equipment type and it can vary from 0.3 to 1 with an 384 average value near 0.6 (see Table 4) (Couper, 2002).

385 Table 4

386 Size factor, interest and period of amortization

\begin{tabular}{cccc}
\hline Main equipment & $\begin{array}{c}\text { Size factor's } \\
\text { exponent }(\mathrm{n})\end{array}$ & Interest rate (i, \%) & $\begin{array}{c}\text { Depreciation period (t, } \\
\text { years) }\end{array}$ \\
\hline MED & 0.53 & 5 & 20 \\
Biomass boiler & 0.50 & 5 & 10 \\
Diesel generator & 0.60 & 5 & 5 \\
Solar fields (thermal & 0.60 & 5 & 15 \\
and PV) & & 5 & 15 \\
\hline
\end{tabular}

388 The water treatment costs are calculated by the Simplified Cost of Water (SCOW) method 389 (Papapetrou et al., 2017) using Eq.13.

$$
\operatorname{SCOW}=\frac{C_{F}+C_{v}}{M_{w}}
$$


390 where $M_{w}$ is the annual volume of water produced, $C_{F}$ the annual fixed costs and $C_{v}$ operating 391 costs.

392 The annual fixed costs (Eq. 14) include the construction of the plant (amortization of the

393 equipment and material), engineering, construction and project management, initial design 394 and permitting and land cost (Papapetrou et al., 2017). According to (Papapetrou et al., 2017), 395 normally, most of these costs are ignored and these are presented as an approximated 396 percentage of the main equipment costs. In this case, the initial design, engineering, 397 construction and project management costs were considered to be included in the MED plant 398 facility cost as it was provided by INERCO Tratamiento de Aguas S.A. In addition, the 399 Municipality of Camarones handed over the land and gave the corresponding permissions 400 free of charge. Normally, the cost of land is never considered as it greatly depends on the 401 plant geographical location.

402

$$
\begin{aligned}
& C_{F}=\sum I_{o} \cdot \alpha \\
& \alpha=\left(\frac{i}{1-(1+i)^{-t}}\right)
\end{aligned}
$$

404 where $I_{o}$ is the initial capital investment, $\alpha$ the amortization factor, $i$ is discount rate and $t$ is 405 depreciation period in years.

406 On the other hand, the variable costs (or operating costs) (Eq. 16) include: reagents and 407 chemical consumptions ( $\left.C_{\text {consumables }}\right)$, energy needed, staff $\left(C_{\text {staff }}\right)$ and maintenance of the 408 facility $\left(C_{\text {maintenance }}\right)$. Regarding the energy needed, electricity consumption was not 409 considered as operating cost because there is no electric network available in the Taltape 410 community (as already mentioned, a diesel generator is used to supply the electric energy 
411 when solar radiation is not available). In this way, the diesel and pellet consumptions used to

412 generate on-site energy are considered within the operating costs $\left(C_{\text {consumables }}\right)$, while the

413 diesel generator and boiler were considered as main equipment in the annual fixed costs.

$$
C_{v}=\left(C_{\text {consumables }}+C_{\text {staff }}+C_{\text {maintenance }}\right)
$$

\section{Results and discussion}

\section{4.1. Dimensioning of the MED and solar thermal field}

419 Table 5 shows the results obtained from the design of the MED plant for distillate productions 420 of $200,500,1,000,2,500$ and 5,000 $\mathrm{m}^{3} /$ day. As shown in the Table 5, the GOR obtained was 4216.9 considering MED plants of 8 stages and a temperature lift (temperature difference 422 between the vapor temperature inside the first and last effects) of $35^{\circ} \mathrm{C}$. As expected, the 423 thermal power required by the distillation process increases proportionally with the plant 424 capacity. These values were used to scale up the $\mathrm{kW}_{\text {th }}$ needed in the biomass boiler and the $425 \mathrm{~kW}_{\mathrm{e}}$ needed in the diesel generator.

426 Table 5

427 Results from the design of the MED plant with different distillate production. All the 428 variables are described in the nomenclature

\begin{tabular}{lccccc}
\hline & 200 & 500 & 1,000 & 2,500 & 5,000 \\
& $\mathrm{~m}^{3} /$ day & $\mathrm{m}^{3} /$ day & $\mathrm{m}^{3} /$ day & $\mathrm{m}^{3} /$ day & $\mathrm{m}^{3} /$ day \\
\hline $\mathrm{Q}_{\mathrm{s}}(\mathrm{kW}$ th $)$ & 775 & 1937.5 & 3,875 & $9,687.5$ & 19,375 \\
\hline $\mathrm{M}_{\mathrm{s}}(\mathrm{kg} / \mathrm{s})$ & 0.4 & 0.8 & 2.0 & 3.3 & 8.0 \\
\hline $\mathrm{GOR}$ & 6.9 & 6.9 & 6.9 & 6.9 & 6.9 \\
\hline $\mathrm{M}_{\mathrm{f}}\left(\mathrm{m}^{3} / \mathrm{h}\right)$ & 18 & 38 & 100 & 165 & 400 \\
\hline
\end{tabular}




\begin{tabular}{lccccc}
\hline A ef $\left(\mathrm{m}^{2}\right)$ & 74 & 170 & 427 & 705 & 1,708 \\
\hline $\mathrm{Pe}_{\mathrm{e}}(\mathrm{kW})^{*}$ & 18.3 & 45.8 & 91.7 & 229.2 & 458.3
\end{tabular}

$429{ }^{*} \mathrm{P}_{\mathrm{e}}$ is the total electric power consumed by the MED plant, which has been determined assuming a specific 430 electric consumption of $2.2 \mathrm{kWh} / \mathrm{m}^{3}$ for all cases.

432 Regarding the solar thermal field, Table 6 shows the results corresponding to the pilot plant 433 installed in Taltape. The resulting solar thermal field is formed by 40 ETC with a total 434 aperture area of $113.2 \mathrm{~m}^{2}$ and an outlet temperature from a solar collector of $88.1^{\circ} \mathrm{C}$.

\section{Table 6}

436 Solar thermal field dimensioning results for the pilot MED plant located in Taltape

\begin{tabular}{cc}
\hline Variables & Values \\
\hline Tout $_{\text {out_series }}$ & $88.1^{\circ} \mathrm{C}$ \\
\hline $\mathrm{N}_{\text {col }}$ & 1 \\
\hline $\mathrm{N}_{\text {rows }}$ & 40 \\
\hline $\mathrm{N}_{\text {total }}$ & 40 \\
\hline $\mathrm{A}_{\mathrm{T}}$ & $113.2 \mathrm{~m}^{2}$
\end{tabular}

438 In order to have a better representation of the behavior of the MED pilot plant located at

439 Taltape with the solar field and biomass boiler, monthly simulations have been performed to 440 determine the solar fraction $\left(\mathrm{F}_{\mathrm{s}}\right)$ and the fresh water produced every month. The results are 441 represented in Fig. 3. The highest solar fraction was obtained in March, 57.8\%, which nearly 442 doubled the solar fraction of the worst month, June, with 31.6\%. The annual average solar 443 fraction was $46.6 \%$, which is represented in Fig. 3 as a dotted line, and the annual energy 444 provided by the solar field was 560.9 GJ. 


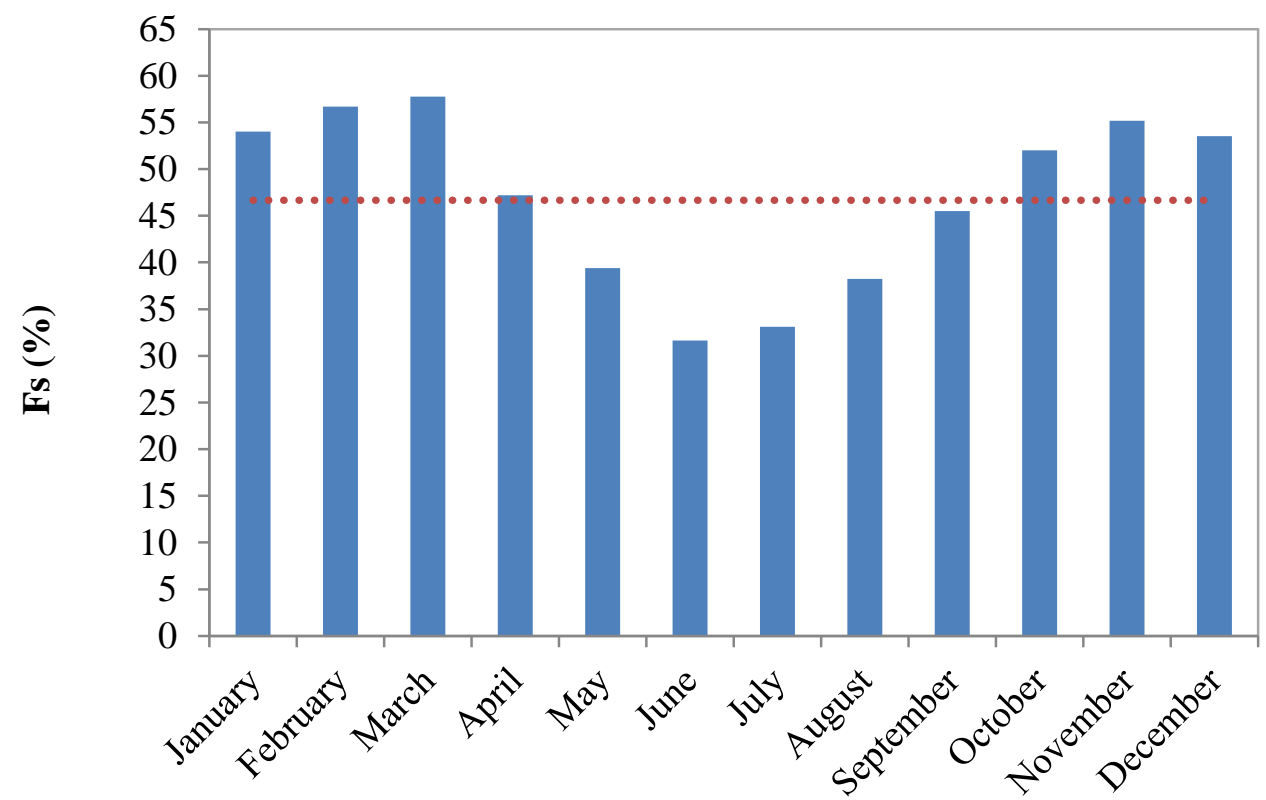

Fig. 3. Monthly solar fraction in Taltape, Arica (blue bars) and annual average solar

450 The ratio between the monthly fresh water produced by solar energy and the monthly fresh

451 water demanded and the same ratio but with the monthly fresh water produced by the biomass

452 boiler (red bars) has been determined in order to have an idea of the solar operation of the

453 MED plant (see Fig. 4). The fresh water demanded is the amount of drinking water, domestic

454 and hygiene use established by UNESCO. As expected, the MED plant will operate mostly 455 with solar energy during summer and spring months (January, February, March, October, 456 November and December), covering between $85-95 \%$ of the freshwater only with solar 457 energy. During autumn and winter months (from April to September), the percentage of use 458 of the boiler is higher, reaching a percentage of nearly $50 \%$ in June. From the annual 459 simulation, a total fresh water production with the MED operating with the thermal energy 460 provided by the solar field of $1,690 \mathrm{~m}^{3}$ was obtained, which means a total of 2,823 hours of 461 solar operation. 


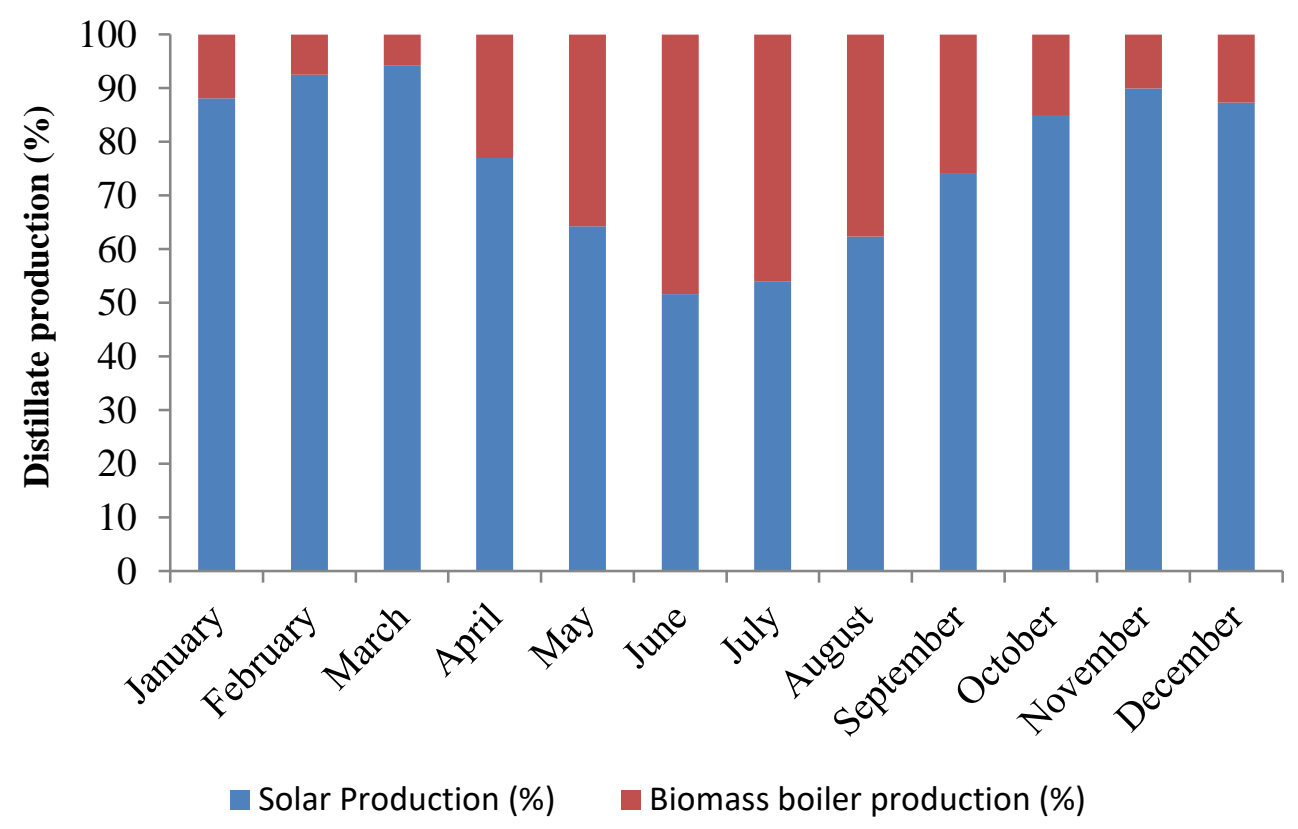

Fig. 4. Relative fresh water production with respect the water demand established by

467 For the rest of cases (the scales-up to higher fresh water capacities), Table 7 shows the size

468 of the solar thermal field in terms of total number of collectors $\left(\mathrm{N}_{\mathrm{T}}\right)$ and total aperture area

$469\left(\mathrm{AT}_{\mathrm{T}}\right)$, the annual thermal energy provided by the solar field $\left(\mathrm{E}_{\mathrm{SF}}\right)$, the annual fresh water 470 produced by solar energy $\left(\mathrm{F}_{\mathrm{Sw}}\right)$ and the annual hours of solar operation $\left(\mathrm{H}_{\mathrm{op}}\right)$ of the MED

471 plant. As can be seen, the solar fraction and hours of operation are kept almost constant in all

472 cases. The rest of parameters are increased in the same scale factor as the capacity (2.5).

\section{$473 \quad$ Table 7}

474 Results from the dimensioning of the solar thermal field and from the annual simulation of 475 the solar water treatment system

\begin{tabular}{ccccccc}
\hline $\begin{array}{c}\text { MED } \\
\text { capacities } \\
\left(\mathrm{m}^{3} / \text { day }\right)\end{array}$ & $\mathrm{N}_{\mathrm{T}}$ & $\mathrm{AT}_{\mathrm{T}}$ & $\mathrm{F}_{\mathrm{s}}(\%)$ & ESF $(\mathrm{GJ})$ & $\left.\mathrm{FSW}_{\text {Sw }} \mathrm{m}^{3}\right)$ & $\mathrm{H}_{\text {op }}(\mathrm{h})$ \\
\hline 200 & 838 & 2372 & 48.9 & $1.2 \cdot 10^{4}$ & $3.5 \cdot 10^{4}$ & 2861 \\
\hline 500 & 2100 & 5943 & 49.0 & $3.0 \cdot 10^{4}$ & $8.9 \cdot 10^{4}$ & 2863 \\
\hline
\end{tabular}




\begin{tabular}{lllllll}
\hline 1000 & 4202 & 11892 & 49.0 & $6.0 \cdot 10^{4}$ & $1.8 \cdot 10^{5}$ & 2864 \\
\hline 2500 & 10504 & 29726 & 49.0 & $1.5 \cdot 10^{5}$ & $4.4 \cdot 10^{5}$ & 2864 \\
\hline 5000 & 21006 & 59447 & 49.0 & $3.0 \cdot 10^{5}$ & $8.9 \cdot 10^{5}$ & 2864
\end{tabular}

476

\subsection{Economical assessment}

478 The initial capital costs (Io in USD\$) accounting for the MED plant, which correspond to the 479 biomass boiler, the diesel generator (installed elements) and the solar thermal and 480 photovoltaic fields are shown in Table 8, together with the annual fixed costs $\left(\mathrm{C}_{\mathrm{F}}\right.$ both in 481 USD $\$$ and USD $\$ / \mathrm{m}^{3}$ ). These costs include the actual values paid to the supplier companies 482 that participated in this initiative (INERCO Tratamiento de Aguas S.A. Madrid, Spain-MED 483 plant-, VIELCO Company - diesel generator- and Nueva Energía -boiler- and 484 SOLUTECHNO, Perú -solar photovoltaic fields-) and a quotation provided by 485 SOLUTECHNO, Perú, according to the results obtained from the size of the solar thermal 486 field. Then, the investment costs for the $10 \mathrm{~m}^{3} /$ day size plant are: $579 \mathrm{USD} \$ / \mathrm{m}^{2}$ for the solar 487 thermal installation including storage, 8.0 USD\$/ $\mathrm{W}_{\mathrm{p}}, 9,400 \mathrm{USD} \$$ for the diesel generator 488 and 11,600 USD \$ for biomass boiler and an initial capital cost of 139,900 USD\$ for the water treatment unit (MED). Assuming the amortization periods and interest rates shown in Table 4904 , the annual fixed cost for the main equipment of the system can be calculated. Notice that 491 only the cost variation caused by the plant scaling up from $10 \mathrm{~m}^{3} /$ day to $200 \mathrm{~m}^{3} /$ day is 492 analyzed in detail in this section in order to simplify the discussion (see Tables 8 and 9).

493 Thus, Table 9 shows the breakdown of the operating costs for the MED plant installed (10 $494 \mathrm{~m}^{3} /$ day $)$ and scaled up $\left(200 \mathrm{~m}^{3} /\right.$ day $)$. When calculating the SCOW, the results are shown in 495 Table 10 for all water treatment capacities considered in this study (from 10 to $5,000 \mathrm{~m}^{3} /$ day).

Table 8

498 Initial capital costs $\left(\mathrm{I}_{0}\right)$ and annual fixed costs $\left(\mathrm{C}_{\mathrm{F}}\right)$ for the main equipment 


\begin{tabular}{|c|c|c|c|c|c|c|}
\hline $\begin{array}{l}\text { Treatment } \\
\text { capacity }\end{array}$ & & $\begin{array}{l}\text { MED } \\
\text { plant }\end{array}$ & $\begin{array}{c}\text { Biomass } \\
\text { boiler }\end{array}$ & $\begin{array}{c}\text { Diesel } \\
\text { generator }\end{array}$ & $\begin{array}{l}\text { Solar thermal } \\
\text { and PV fields }\end{array}$ & Total \\
\hline \multirow{4}{*}{$10 \mathrm{~m}^{3} /$ day } & $\begin{array}{c}\mathrm{I}_{0} \\
\text { (USD\$) }\end{array}$ & 139,900 & 11,600 & 9,400 & 90,500 & 251,400 \\
\hline & $\begin{array}{c}\mathrm{C}_{\mathrm{F}} \\
(\mathrm{USD} \$)\end{array}$ & 11,200 & 1,500 & 2,200 & 8,700 & 23,600 \\
\hline & $\begin{array}{c}\mathrm{C}_{\mathrm{F}} / \mathrm{M}_{\mathrm{w}} \\
\left(\mathrm{USD} \$ \mathrm{~m}^{3}\right)\end{array}$ & 3.2 & 0.4 & 0.6 & 2.5 & 6.7 \\
\hline & $\begin{array}{l}\text { Relative } \\
\text { cost }(\%)\end{array}$ & 47.5 & 6.1 & 8.9 & 35.4 & - \\
\hline \multirow{5}{*}{$200 \mathrm{~m}^{3} /$ day } & $\begin{array}{c}\mathrm{I}_{0} \\
(\mathrm{USD} \$)\end{array}$ & 684,500 & 51,900 & 30,000 & 561,500 & $1,327,900$ \\
\hline & $\begin{array}{c}\mathrm{C}_{\mathrm{F}} \\
(\mathrm{USD} \$)\end{array}$ & 54,900 & 6,700 & 4,850 & 54,100 & 120,550 \\
\hline & $\begin{array}{c}\mathrm{C}_{\mathrm{F}} / \mathrm{M}_{\mathrm{w}} \\
\left(\mathrm{USD} \$ / \mathrm{m}^{3}\right)\end{array}$ & 0.78 & 0.10 & 0.07 & 0.77 & 1.7 \\
\hline & $\begin{array}{l}\text { Relative } \\
\text { cost }(\%)\end{array}$ & 45.5 & 5.3 & 3.9 & 43.2 & \\
\hline & $\begin{array}{l}\text { Reduction } \\
(\%)\end{array}$ & 75.6 & 75.0 & 88.3 & 69.2 & 74.6 \\
\hline
\end{tabular}

500 It should be highlighted that the MED plant implementation together with the solar fields, 501 represent the higher relative $C_{F}$ of the main equipment, concretely 3.2 and 2.5 USD\$ per $\mathrm{m}^{3}$ 502 treated at the smallest scale, respectively (see Table 8). If the treatment capacity of the MED 503 plant is increased to $200 \mathrm{~m}^{3} /$ day, these costs can be reduced to 0.78 and 0.77 USD $\$$ per $\mathrm{m}^{3}$ 504 treated, following the same order. Also, the $\mathrm{C}_{\mathrm{F}}$ of the diesel generator and biomass boiler can 505 be diminished considerably, 88.3 and $75.0 \%$ respectively. Thus, the total annual fixed costs 506 per $\mathrm{m}^{3}$ treated are reduced in $74.6 \%$, i.e. from 6.7 USD $\$$ per $\mathrm{m}^{3}$ to $1.8 \mathrm{USD} \$$ per $\mathrm{m}^{3}$.

507 On the other hand, the breakdown of operating consumptions is summarized in Table 9. As 508 commented in previous sections, the costs were obtained considering 350 operating days per 509 year that correspond to $70 \cdot 10^{3} \mathrm{~m}^{3}$ treated per year and $24 / 7$ operating regime and were also 510 scaled from $10 \mathrm{~m}^{3} /$ day to $200 \mathrm{~m}^{3} /$ day. The operating and maintenance costs were obtained 511 taking into account the reagents and chemical consumptions shown in Section 3.3 The main 512 consumptions are also described in Table 9. The maintenance cost was considered as $2 \%$ of 
513 annual fixed cost according (Papapetrou et al., 2017) and the staff costs were considered as

5140.03 USD\$ per $\mathrm{m}^{3}$ treated (Kesieme et al., 2013). The chemicals and consumables taken into

515 account were: (i) Anti-fouling with a consumption of $0.01 \mathrm{~L} / \mathrm{h}$ for $10 \mathrm{~m}^{3} /$ day and $0.02 \mathrm{~L} / \mathrm{h}$

516 for $200 \mathrm{~m}^{3} /$ day. The anti-fouling consumptions was provided by INERCO. This consumption

517 is only considered in the inlet to to the process. (ii) Diesel consumptions was considered 3.7

$518 \mathrm{~L} / \mathrm{h}$ for $12 \mathrm{~kW}$ for $10 \mathrm{~m}^{3} /$ day and $5.9 \mathrm{~L} / \mathrm{h}$ for $45.8 \mathrm{~kW}_{\mathrm{e}}$ for $200 \mathrm{~m}^{3} /$ day. The data of diesel

519 consumptions were obtained from Worldwide Power Products LLC, approximate the fuel

520 consumptions of a diesel generator based on the size of the generator; (iii) Oil consumptions

521 was considered that each $250 \mathrm{~h}$ of operation the oil must be changed 6.5L; (iv) Refrigerant

522 consumptions was considered that each 1,000 h of operation the refrigerant must be changed

$5238 \mathrm{~L} ;(\mathrm{v})$ the biomass consumption were calculated as $4.9 \mathrm{~kg} / \mathrm{h}$ for $38,6 \mathrm{~kW}$ th for $10 \mathrm{~m}^{3} / \mathrm{h}$ and

$52463.2 \mathrm{~kg} / \mathrm{h}$ for $775 \mathrm{~kW}$ th for $200 \mathrm{~m}^{3} / \mathrm{h}$, (vi) and finally the Sulfamic acid $5 \%$ was considered

525 as acid cleaning once per year.

526 Table 9

527 Breakdown of operating costs for MED plant installed (10 $\mathrm{m}^{3} /$ day) and scaled up (200

$528 \quad \mathrm{~m}^{3} /$ day)

\begin{tabular}{|c|c|c|c|c|c|c|}
\hline \multirow{3}{*}{ Operating costs } & \multicolumn{3}{|c|}{$10 \mathrm{~m}^{3} /$ day } & \multicolumn{3}{|c|}{$200 \mathrm{~m}^{3} /$ day } \\
\hline & $\mathrm{C}_{\mathrm{v}}$ & $\begin{array}{c}\text { Relative } \\
\text { cost }\end{array}$ & $\mathrm{C}_{\mathrm{v}} / \mathrm{M}_{\mathrm{w}}$ & $\mathrm{C}_{\mathrm{v}}$ & $\begin{array}{c}\text { Relative } \\
\text { cost }\end{array}$ & $\mathrm{C}_{\mathrm{v}} / \mathrm{M}_{\mathrm{w}}$ \\
\hline & USD\$ & $\%$ & $\mathrm{USD} \$ / \mathrm{m}^{3}$ & USD\$ & $\%$ & $\mathrm{USD} \$ / \mathrm{m}^{3}$ \\
\hline Staff $\left(0.03 \text { USD } \$ / \mathrm{m}^{3}\right)^{\mathrm{a}}$ & 110 & 0.4 & 0.03 & 2,100 & 1.8 & 0.03 \\
\hline Maintenance $\left(2 \% \mathrm{I}_{0}\right)^{\mathrm{b}}$ & 5,100 & 18.2 & 1.46 & 26,400 & 22.4 & 0.39 \\
\hline \multicolumn{7}{|l|}{ Chemicals and consumables } \\
\hline Anti-fouling $(0.01 \mathrm{~L} / \mathrm{h})$ & 950 & 3.4 & 0.27 & 1,900 & 1.6 & 0.03 \\
\hline $\begin{array}{r}\text { Diesel consumptions } \\
\text { Semi-industrial, } 10 \mathrm{~m}^{3} / \mathrm{day}: \\
12 \mathrm{~kW}_{\mathrm{e}} \text { consumption } 3.7 \mathrm{~L} / \mathrm{h} \\
\text { MED plant scaled, } 200 \mathrm{~m}^{3} / \mathrm{day}: \\
45.8 \mathrm{~kW}_{\mathrm{e}} \text { consumption } 5.9 \mathrm{~L} / \mathrm{h}\end{array}$ & 12,800 & 45.6 & 3.7 & 20,600 & 17.5 & 0.29 \\
\hline Oil (change each $250 \mathrm{~h}, 6.5 \mathrm{~L}$ ) & 1,350 & 4.8 & 0.38 & 3,000 & 2.6 & 0.04 \\
\hline $\begin{array}{r}\text { Refrigerant (change each } 1000 \\
\mathrm{~h}, 8 \mathrm{~L})\end{array}$ & 250 & 0.9 & 0.07 & 500 & 0.4 & 0.007 \\
\hline Biomass: Pellets & 7,400 & 26.4 & 2.1 & 63,000 & 53.6 & 0.9 \\
\hline
\end{tabular}


Semi-industrial, $10 \mathrm{~m}^{3} /$ day: $38,6 \mathrm{~kW}_{\text {th }}$ consumption $4.9 \mathrm{~kg} / \mathrm{h}$

MED plant scaled, $200 \mathrm{~m}^{3} /$ day:

$775 \mathrm{~kW}_{\text {th }}$ consumption 63.2

$\mathrm{kg} / \mathrm{h}$

\begin{tabular}{|c|c|c|c|c|c|c|}
\hline $\begin{array}{r}\text { Sulfamic Acid 5\% (once per } \\
\text { year) }\end{array}$ & 75 & 0.3 & 0.02 & 75 & 0.06 & 0.001 \\
\hline TOTAL & 28,035 & & 8.0 & 117,575 & & 1.7 \\
\hline
\end{tabular}

${ }^{\mathrm{a}}$ Kesieme et al., 2013, ${ }^{\mathrm{b}}$ Papapetrou et al., 2017

530 The diesel and biomass consumptions together with the maintenance, represent the most

531 important part of the operating costs associated with the treatment both at small $\left(10 \mathrm{~m}^{3} /\right.$ day $)$

532 and large scale (200 $\mathrm{m}^{3} /$ day). Previously, the highest cost was the diesel consumption, 3.7

533 USD $\$ \mathrm{~m}^{3}$, which represents $45.6 \%$ of the total operating costs, followed by the pellets

534 consumption (2.1 USD $\$ / \mathrm{m}^{3}, 26.4 \%$ relative cost) and maintenance (1.48 USD $\$ / \mathrm{m}^{3}, 18.2 \%$

535 relative cost). However, the order changes at large scale (from 200 to $5,000 \mathrm{~m}^{3} /$ day), where

536 the pellets consumption presents by far the highest relative cost $\left(0.9 \mathrm{USD} \$ / \mathrm{m}^{3}, 53.6 \%\right)$,

537 followed by maintenance $\left(0.39 \mathrm{USD} \$ / \mathrm{m}^{3}, 22.4 \%\right)$ and diesel consumption $\left(0.29 \mathrm{USD} \$ / \mathrm{m}^{3}\right.$,

$53817.5 \%)$. The absolute increase in the diesel consumption due to the scaling up of the solar

539 water treatment system is much lower than the absolute increase in the pellets consumption.

540 Antifouling chemicals and oil for the electric generator represent about a 4\% relative cost

541 each at small-scale and about $2 \%$ each at large-scale while staff salaries and sulfamic acid

542 consumption present almost negligible costs regardless of the scale. The solar water treatment

543 system scaling up allows a reduction of $78.7 \%$ in the total operating costs, which diminished

544 from 8.0 USD\$ per $\mathrm{m}^{3}$ treated for small scale to $1.7 \mathrm{USD} \$$ per $^{3}$ treated for large scale.

545 The cost of distillated water produced by the MED plant, SCOW, varies from $15.0 \mathrm{USD} \$ / \mathrm{m}^{3}$

546 for the $10 \mathrm{~m}^{3} /$ day production capacity to $3.2 \mathrm{USD} \$ / \mathrm{m}^{3}$ when this variable is increased to 200

$547 \mathrm{~m}^{3} /$ day, which is equivalent to a $76.7 \%$ reduction (see Table 10 ). These high costs obtained 
548 are clearly affected by the economy of scale and, mainly, due to use of diesel generator and

549 biomass boiler, since the water treatment system is located in a remote arid area where the

550 lack of electric grid and transport is a determinant factor.

551 As has been expressed during the whole study, the plant treatment capacity is extremely

552 important for the SCOW. Therefore, a final study in which the relationship between these

553 two variables is analyzed was carried out and it is presented in Fig. 5 and Table 10. These

554 costs were calculated following the same sequence explained in Section 3.3. The highest cost

555 reduction was observed in the case exposed above, i.e. when the MED production capacity

556 was increased from 10 to $200 \mathrm{~m}^{3}$ per day, resulting in $76.7 \%$ SCOW reduction. The next

557 analyzed level was $500 \mathrm{~m}^{3} /$ day, which represented $37.1 \%$ SCOW improvement with respect

558 to the previous case while varying from $500 \mathrm{~m}^{3} /$ day to $1,000 \mathrm{~m}^{3} /$ day resulted in $20.2 \%$ SCOW

559 decrease. Thus, increasing the MED treatment capacity always results in the improvement of

560 the SCOW. However, this improvement gets lower with each MED treatment capacity

561 increase so that, finally, it becomes negligible.

562 Table 10

563 The SCOW and reduction percentage achieved for different treatment capacities.

\begin{tabular}{ccc}
\hline Treatment capacity $\left(\mathrm{m}^{3} /\right.$ day $)$ & SCOW $\left(\mathrm{USD} \$ / \mathrm{m}^{3}\right)$ & Reduction percentage $(\%)$ \\
\hline 10 & 15.0 & \\
200 & 3.20 & 76.7 \\
500 & 2.20 & 85.3 \\
1,000 & 1.76 & 88.3 \\
2,500 & 1.40 & 90.7 \\
5,000 & 1.25 & 91.6 \\
\hline
\end{tabular}




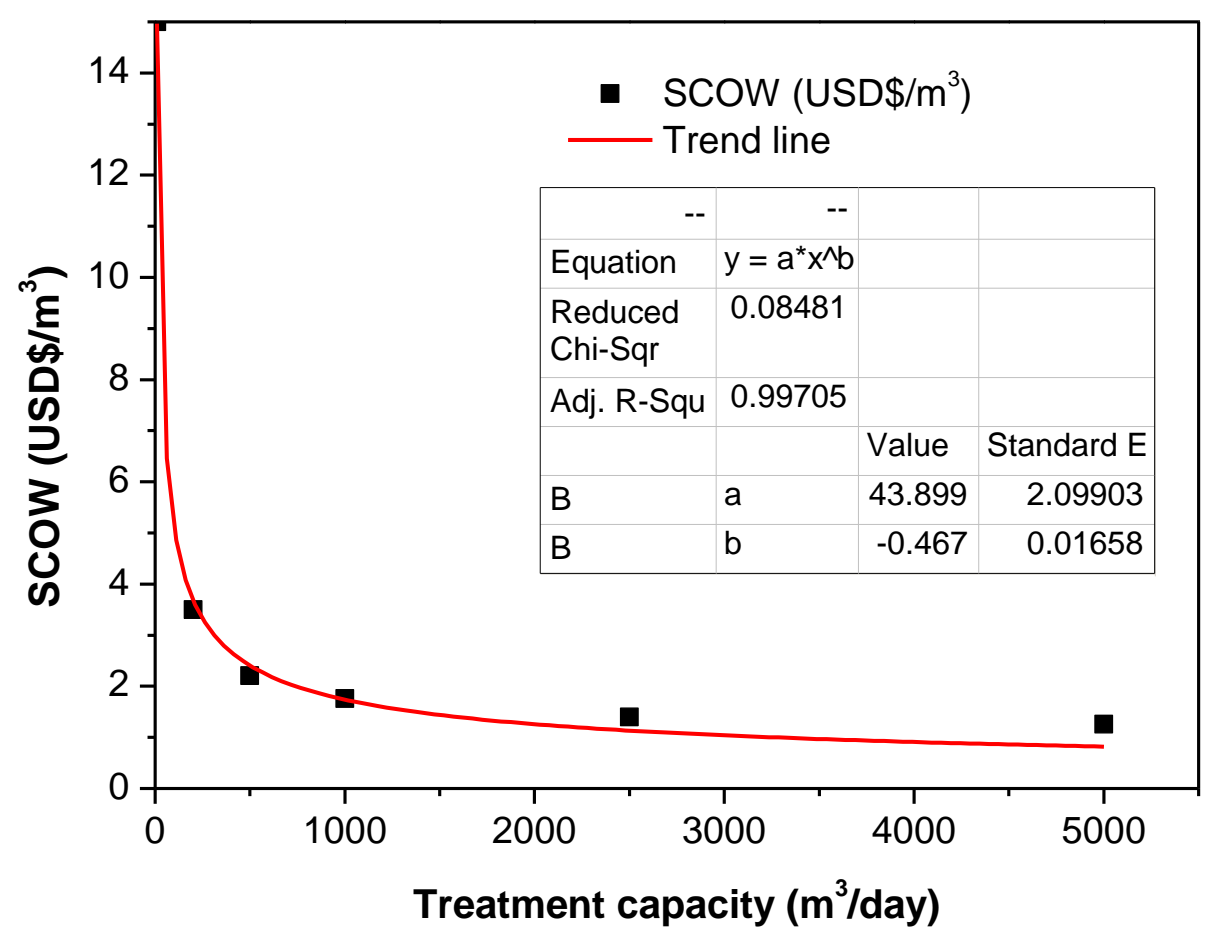

Fig. 5. Simplified Cost of Water (SCOW) versus treatment capacity $\left(\mathrm{m}^{3} / \mathrm{day}\right)$.

\section{Conclusions}

567 This paper presents the simulation of a MED pilot plant located in a remote community of

568 the north of Chile (Taltape) that will be used to improve its agricultural activity and for

569 domestic and hygiene purposes. From the operation of this plant, it has been demonstrated

570 that the_water treatment process allows diminishing As and B in $99 \%$ and $95 \%$, respectively.

571 The water treatment system will be coupled to a static solar thermal field to make it more

572 sustainable taking advantage of the high solar radiation of the location. The whole system

573 has been simulated along a whole year using meteorological data from Taltape in order to

574 assess the solar operation of the water treatment plant and determine the use of a biomass

575 boiler as a backup when the solar radiation is not available. An annual solar fraction of $46.6 \%$

576 and a total fresh water production with the MED operating with solar energy of 1,690 $\mathrm{m}^{3}$

577 have been obtained, which make a total of 2,823 hours of exclusive solar operation. It means 
578 that the needs of the community can be fully covered during most of the year with the solar

579 field, making a higher use of the biomass boiler (up to 48\%) from May to August.

580 An economic assessment has been also performed in order to study the water costs of the

581 MED pilot plant and they scaled up to 5,000 $\mathrm{m}^{3} /$ day. The cost of distillated water produced 582 by the MED plant varied from $15.0 \mathrm{USD} \$ / \mathrm{m}^{3}$ for the $10 \mathrm{~m}^{3} /$ day production capacity to 1.25

$583 \mathrm{USD} \$ / \mathrm{m}^{3}$ when this variable is increased to $5,000 \mathrm{~m}^{3} /$ day, which is equivalent to a $91.6 \%$

584 reduction. It was found that the MED plant implementation and solar fields represent the

585 higher relative annual fixed cost of the main equipment while the diesel and biomass 586 consumptions together with the maintenance represent the most important part of the 587 operating costs.

\section{Acknowledgments}

591 PhD. Lorena Cornejo Ponce wishes to thank the Region Government of Arica\&Parincota 592 (FIC Taltape BIP code 30158422-0). PhD. Sara Miralles-Cuevas wishes to thank the Solar 593 Energy Research Center for her post-doctoral position in Arica, Chile, under SERC-Chile, 594 FONDAP project (reference: 15110019). PhD. Alejandro Cabrera wishes to thank his post595 doctoral position at University of Tarapacá. Patricia Palenzuela wishes to thank funding 596 support from the Spanish Ministry of Economy and Competitiveness and ERDF funds under 597 the National R+D+I Plan Project DPI2014-56364-C2-2-R. 
602 Abejón, A., Garea, A., Irabien, A., 2015. Arsenic removal from drinking water by reverse 603 osmosis: Minimization of costs and energy consumption, Separation and Purification 604 Technology 144, 46-53.

605 Andrés-Mañas, J.A., Palenzuela, P., Cornejo, L., Alarcón-Padilla, D.C., Acién, G., Zaragoza, 606 G., 2017. Preliminary evaluation of the use of vacuum membrane distillation for the 607 production of drinking water in Arica (Chile), Desalination \& Water Treatment 61, 160-169.

608 Bhattacharjeea, P., Chatterjeea, D., Singhb, K., Giri, A., 2013. Systems biology approaches 609 to evaluate arsenic toxicity and carcinogenicity: an overview. Int. J. Hyg. Environ. Health. $610216,574-586$.

611 Bick, A., Oron, G., 2005. Post-treatment design of seawater reverse osmosis plants: Boron 612 removal technology selection for potable water production and environmental control, 613 Desalination 178, 233-246.

614 Bundschuh, J., Litter, M., Ciminelli, V.S.T., Morgada, M.E., Cornejo, L., Hoyos, S.G., 615 Hoinkis, J., Alarcón-Herrera, M.T., Armienta, M.A., Bhattacharya, P., 2010. Emerging 616 mitigation needs and sustainable options for solving the arsenic problems of rural and isolated 617 urban areas in Latin America - A critical analysis. Water Research 44 (19), 5828-5845.

618 Choong, T.S.Y., Chuah, T.G., Robiah, Y., Gregory Koay, F.L., Azni, I., 2007. Arsenic 619 toxicity, health hazards and removal techniques from water: an overview, Desalination 217 $620 \quad(1-3), 139-166$.

621 Chorak, A., Palenzuela, P., Alarcón-Padilla, D.C., Abdellah, A.B., 2017. Experimental 622 characterization of a multi-effect distillation system coupled to a flat plate solar collector 623 field: empirical correlations, Applied Thermal Engineering 120, 298-313. 
624 Couper, J.R., 2002. Process Engineering Economics, Chapter 4, page 70, CRC Press Ed.

625 Darwish, M., Hassan, A., Mohtar, R., 2013. Toward Implementing HH the Amir

626 Declaration of 2\% Electricity Generation by Solar Energy in 2020, Energy and Power

627 Engineering 5, 245-258.

628 Decreto Supremo 143/2009. Normas de calidad primaria para las aguas continentales

629 superficiales aptas para actividades de recreación con contacto directo

630 (https://www.leychile.cl/Navegar?idNorma=288386).

631 Decreto Supremo 144/2009. Normas de calidad primaria para la protección de las aguas

632 marinas y estuarinas aptas para actividades de recreación con contacto directo

633 (https://www.leychile.cl/Navegar?idNorma=1001042).

634 Directive 98/83/EC. European Union, Council Directive 98/83/EC on the quality of water 635 intended for human consumption.

636 El-Dessouky, H., Ettouney, H., 2002. Fundamentals of Salt Water Desalination, $1^{a}$ ed.

637 Amsterdam, The Netherlands: ELSEVIER SCIENCE B.V, 2002.

638 El-Nashar, A.M. and Ishii, K., 1985. Abu Dhabi solar distillation plant, Desalination 52, 217639234.

640 El-Nashar, A.M., Qamhiyeh, A.A., 1995. Simulation of the steady-state operation of a multi641 effect stach seawater distillation plant, Desalination 101, 231-243.

642 Fernández-Izquierdo, P., García-Rodríguez, L., Alarcón-Padilla, D., Palenzuela, P., Martín643 Mateos, I., 2012. Experimental analysis of a multi-effect distillation unit operated out of 644 nominal conditions, Desalination 284, 233-237. 
645 GLASS Report, 2014. UN-Water Global Analysis and Assessment of Sanitation and 646 Drinking-Water GLAAS Report.

647 Hanel, M., Escobar, R., 2013. Influence of solar energy resource assessment uncertainty in 648 the levelized electricity cost of concentrated solar power plants in Chile, Renewable Energy $649 \quad 49,96-100$.

650 Hilal, N., Kim, G.J., Somerfield, C., 2011. Boron removal from saline water: A 651 comprehensive review, Desalination 273, 23-35.

652 Hong-Jie, S., Bala, R., Bing, W., Jun, L., Li-Ping, P., Lena, M., 2014. Arsenic and selenium 653 toxicity and their interactive effects in humans. Environ. Int. 69, 148-158.

654 Kesieme, U.K., Milne, N., Aral, H., Cheng, C.Y., Duke, M., 2013. Economic analysis of 655 desalination technologies in the context of carbon pricing, and opportunities for membrane 656 distillation, Desalination 323, 66-74, http://dx.doi.org/10. 1016/j.desal.2013.03.033.

657 Li, C., Goswami, Y., Stefanakos, E., 2013. Solar assisted sea water desalination: a review, 658 Renew. Sust. Energ. Rev. 19, 136-163.

659 López, D.L., Bundschuh, J., Birkle, P., Armienta, M.A., Cumbal, L., Sracek, O., Cornejo, 660 L. , Ormachea, M., 2012. Arsenic in volcanic geothermal fluids of Latin America, Science 661 of the Total Environment 429, 57-75.

662 Mohtar, R. and Darwish, M., 2013. Prime Energy Challenges for Operating Power Plant in 663 GCC, Energy and Power Engineering 5, 109-128.

664 Öztürk, N., Kavak, D., Köse, T.E., 2008. Boron removal from aqueous solution by reverse 665 osmosis, Desalination 223, 1-9. 
666 Palenzuela, P., Hassan, A.S., Zaragoza, G., Alarcón-Padilla, D.C., 2014. Steady-state model 667 for multi-effect distillation case study: Plataforma Solar de Almería MED pilot plant, 668 Desalination 337, 31-42.

669 Palenzuela, P., Alarcón-Padilla, D.C., Zaragoza, G., 2016. Experimental parametric analysis 670 of a solar pilot-scale multi-effect distillation plant, Desalination \& Water Treatment 57, $671 \quad 23097-23109$.

672 Papapetrou, M., Cipollina, A., La Commare, U., Micale, G., Zaragoza, G., Kosmadakis, G., 673 2017. Assessment of methodologies and data used to calculate desalination costs, 674 Desalination 419, 8-19.

675 Seider W.D., Seader J.D., Lewin D.R., 2004. Product and Process Design Principles: 676 Synthesis, Analysis and Evaluation, 2nd Ed, Wiley.

677 Valenzuela, C., Mata-Torres, C., Cardemil, J.M., Escobar, R.A., 2017. CSP+PV hybrid solar 678 plants for power and water cogeneration in northern Chile, Solar Energy 157, 713-726.

679 Wang, Q., Zhang, G.S., Chen, H., Wang, P., 2016. Enhanced As(III) removal at low 680 concentrations by the combined pre-oxidation and nanofiltration membrane process, 681 Desalination and Water Treatment 57 (59), 28947-28956.

682 WHO, 2016. Evaluations of the Joint FAO/WHO Expert Committee on Food Additives 683 (JECFA): arsenic data. http://www.who.int/mediacentre/factsheets/fs372/en/

684 WHO and UNICEF, 2017. Progress on drinking water, sanitation and hygiene: 2017 update 685 and SDG baselines. Geneva: World Health Organization (WHO) and the United Nations 686 Children's Fund (UNICEF), 2017. Licence: CC BY-NC-SA 3.0 IGO. ISBN 978-92-4$687 \quad 151289-3$. 
688 Yang, Y., Lior, N., 2006. Performance analysis of combined humidified gas turbine power 689 generation and multi-effect thermal vapour compression desalination systems Part1: the 690 desalination unit and its combination with a steam-injected gas turbine power system, 691 Desalination 196, 84-104.

692 Yunus, M., Sohel, N., Kumar Hore, S., Rahman, M., 2011. Arsenic exposure and adverse 693 health effects: a review of recent findings from arsenic and health studies in Matlab, 694 Bangladesh. Kaohsiung. J. Med. Sci. 27, 371-376. 